\title{
IMPROVING THE STRENGTH OF SANDY SILT SOILS BY MIXING WITH CEMENT KILN DUST
}

\author{
Mohie EIMashad, Ahmed Hashad * \\ Construction Research Institute, National Water Research Center, Egypt
}

Received 21 May 2013, accepted 1 July 2013

\begin{abstract}
Egyptian irrigation and drainage system consists of the River Nile, its branches, canals and drains. It is very important to keep them working in good condition to assure efficient water management and distribution process. Water channel embankments made of sandy silt soils are exposed to slope stability problems. These problems are considered one of the common canal embankments problems in the delta of Nile River. Soil improvement is one of the most economic engineering solutions to overcome soil problems.

This research studying the improving of sandy silt soils by mixing with cement kiln dust. Laboratory tests were carried out to evaluate the improved soil properties. Three numerical models were built for an embankment of a canal to examine the introduced method to overcome slope stability problems. The natural soil slope stability safety factor was calculated from the first numerical model. The second model used to calculate safety factor after applying the improved soil properties that were determined from the laboratory works. The third numerical model was built to simulate improving natural soil by using the traditional soil reinforcement technique. The results for the two improvement methods were compared.

The results showed that the proposed method caused significant improvement for slope stability of the sandy silt soil. The proposed method has the advantage of using with existing or new structures.
\end{abstract}

Keywords: Soil improvement, soil mixing, cement dust, slope stability, barrages.

\section{Introduction}

Cement manufacturing is one of the largest industries in Egypt. The production of cement in Egypt reaches 48 million tons and discards about 3 million tons of cement dust per year. This huge quantity of dust generates continuous problems for both cement makers and governments in addition to significant financial losses. During the manufacture of Portland cement, a large amount of dust is collected from kiln exhaust gases and disposed in landfills. The Cement Kiln Dust (CKD) has cementitious properties that make it an effective stabilizer for certain soil types. CKD represents a potentially useful and cost-effective alternative to other soil stabilizers such as lime, fly ash and Portland cement. CKD is being used increasingly for soil stabilization. Most of barrages in Egypt have been built many years ago using masonry bricks without reinforcement. The main problem of the masonry structures is their low resistance to tensile stresses. Masonry structures also sensitive to lateral load such as lateral earth pressure on structure abutments. It is essential to protect the barrage structures from the risk of failure due to soil problems due to their importance in the Egyptian irrigation system. Poor base soil conditions can result in inadequate bearing capacity, excessive lateral earth pressure or settlement problems which lead to reduce structure life time. Soil improvement is one of the most economic engineering solutions to overcome most of soil problems. Soils may be improved by applying mechanical effort or by adding chemical or cementitious additives. Soil mixing technique is considered one of the most promising soil

\footnotetext{
* Corresponding author.

E-mail address: a@earth-egypt.com
} 
Mohie ElMashad, Ahmed Hashad, Improving the strength of sandy silt soils by mixing with cement kiln dust, PP. 1421 - 1431

improvement methods. The importance of this technique will be increased especially when using the waste of some industrial materials to be mixed with soil. CKD can be used as a cementious material with a variety of soils to improve their engineering properties.

This research introduces method to improve sandy silt soils by mixing it with CKD. This method could be efficient in improving the safety factor for embankments slopes of irrigation channels.

Many researchers have studied the effect of mixing soils with CKD. IEEE-IAS Cement Industry Committee [1] stated that the CKD has been used extensively as a binder in soil stabilized base and subbase pavement applications. Robert L. Parsons, et al [2] studied the durability of mix by carrying out durability testing procedures including freeze-thaw, wetdry, and leach testing. Atterberg limits and strength tests were also conducted before and after selected durability tests. Relative values of soil stiffness were also tracked over a 28-day curing period using the soil stiffness gauge. Treatment with cement dust was found to be an effective option for improvement of soil properties, based on the testing conducted as a part of this research. Strength and stiffness were improved while plasticity and swell potential were substantially reduced. Mohie [3] found that the compaction characteristic of sand was improved by mixing with CKD. Considering the seepage control and compressive strength, cement dust was approved to have more pronounced effect on the reduction of the sand permeability and enhancing of the compressive strength of sand. P.V.Koteswara, et al [4] concluded that the clays can be thoroughly modified by admixture stabilization and fiber reinforcement, provided that effective mixing methods are available. The CKD can be utilized in pavement construction as the CBR of the CKD soil mix is significant even in soaked condition. Use of fibers is greatly affecting the stress strain behavior of the CKD soil mix. Addition of CKD significantly reduced the soil plasticity index.

The data presented in this research lends further credibility to use CKD for soil stabilization under appropriate conditions. The results of the introduced method can be applied for new slopes and can be used to solve impacts of soil pressure on the retaining walls or to solve weak soil base problems.

\section{Experimental work}

The proposed soil improvement method depends on increasing the cohesion by mixing natural sandy silt soil with CKD. Experimental program was designed to assess the effectiveness of the suggested method and to determine the optimum values of CKD mixing ratios with soil. A number of laboratory tests were carried out to determine the soil properties before and after the improvement using three mixtures with different mixing ratio. The tested samples were taken from the three mixtures in addition to the natural sandy silt soil. The mixtures were formed using CKD ratio of $10 \%, 15 \%$, and $30 \%$ respectively to be mixed with the natural sandy silt soil. The following sections describe the material used in experiments and tests results.

\subsection{Materials}

\subsubsection{CKD}

CKD in general contains chlorides, sulphates, alkalies and calcium oxides that can contain from $8-61 \%$ total $\mathrm{CaO}$, and from zero $-37 \%$ free lime. Free lime is the amount of lime that is

Journal of Engineering Sciences, Assiut University, Faculty of Engineering, Vol. 41, No. 4, July, 2013,E-mail address: jes@aun.edu.eg 
Mohie ElMashad, Ahmed Hashad, Improving the strength of sandy silt soils by mixing with cement kiln dust, PP. 1421 - 1431

available for reactions, and is a good indicator of how reactive a CKD will be. This lime content makes it attractive to use as a neutralization agent (Mackie et al. 2010) [7].

\subsubsection{Sandy silt soil}

The considered natural soil needs to be improved in this research was sandy silt with traces of clay soil. This type of soil constitutes a soil layer of most of the canal embankment in the Nile delta of Egypt.

\subsection{Experimental tests}

The laboratory tests used to determine soil properties are grain size distribution test, specific gravity test, compaction test, California bearing ratio (CBR), unconfined compression test, unconsolidated undrained triaxial test and the permeability test. Tests and its results are explained and discussed in the following sections.

\subsubsection{Grain size distribution}

Grain size distribution test was performed in accordance with the ASTM-D422 test method for particle size analysis of soils. Soil is classified according to the Unified Soil Classification System (USCS) (test method for classification of soils for engineering purposes). Figure 1 shows the grain size distribution curves for the natural sandy silt soil, the used CKD and the three used mixtures in the same graph. It can be noticed from the grain size distribution curves that the cement kiln dust particles are in the size zone of silt.

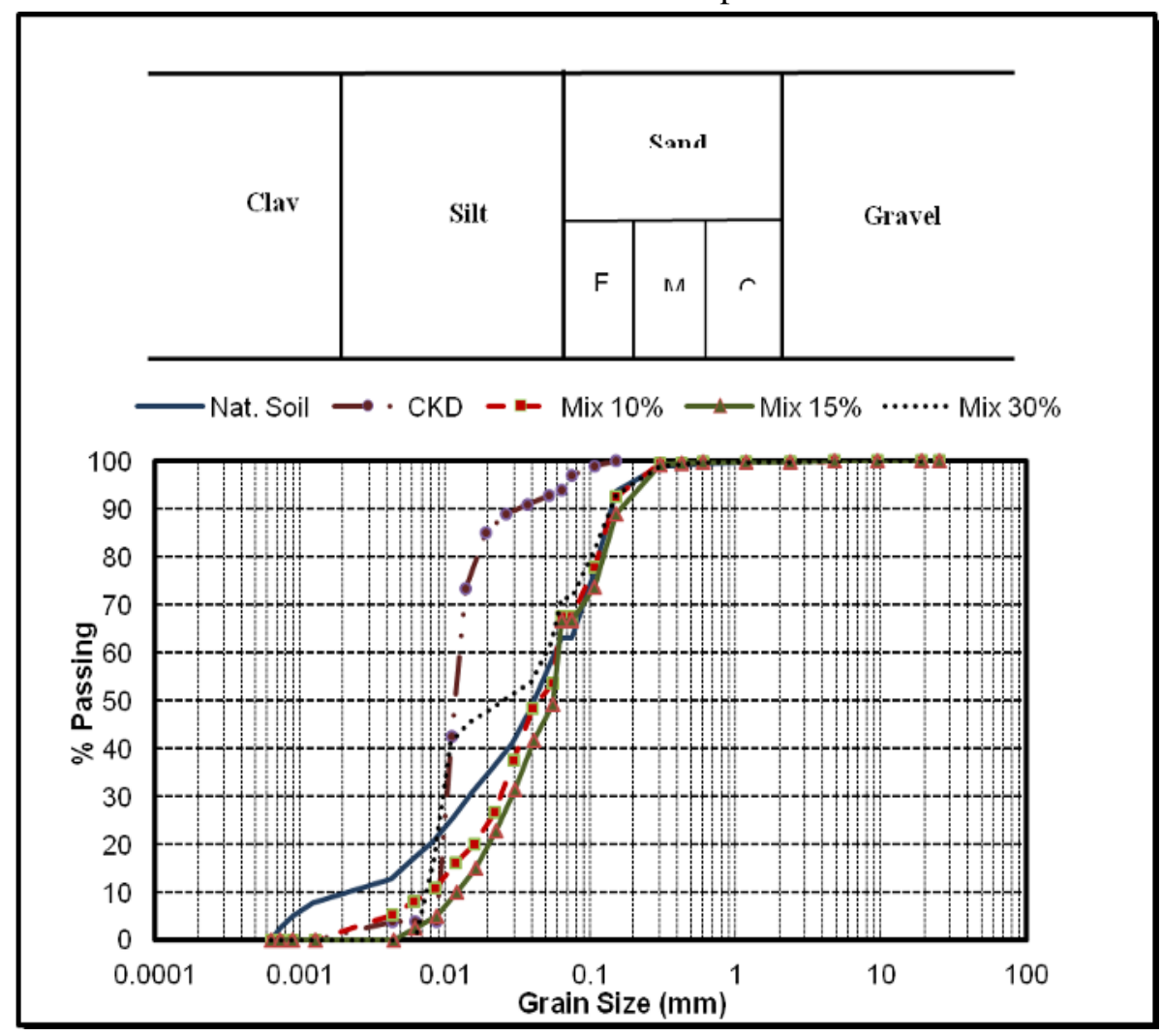

Fig. 1. Grain size distribution curves

Journal of Engineering Sciences, Assiut University, Faculty of Engineering, Vol. 41, No. 4, July, 2013,E-mail address: jes@aun.edu.eg 
1424

Mohie ElMashad, Ahmed Hashad, Improving the strength of sandy silt soils by mixing with cement kiln dust, PP. 1421 - 1431

\subsubsection{Specific Gravity}

The specific gravity of the natural soil and the three mixtures are summarized in table (1). The results show that the CKD has the maximum specific gravity value. The value of the specific gravity of other mixtures increases as the CKD ratio increases.

\section{Table 1.}

Specific gravity of the mixtures

\begin{tabular}{|l|c|c|c|c|c|}
\hline Soil Properties & Nat. Soil & CKD & Mix 10\% & Mix 15\% & Mix 30\% \\
\hline Specific Gravity & 2.56 & 3.12 & 2.64 & 2.65 & 2.70 \\
\hline
\end{tabular}

\subsubsection{Compaction test results}

The modified compaction test is applied to determine the maximum dry density for each mixture. The compaction curves for natural soil and the three mixtures were plotted in Figure (2). The natural soil has the maximum dry density of $1.83 \mathrm{~g} / \mathrm{cm}^{3}$ at O.M.C of $18.4 \%$. The results in related to $10 \%$ CKD mix ratio show that increase the CKD ratio will lead to insignificant increase in the dry density and decreases the O.M.C.

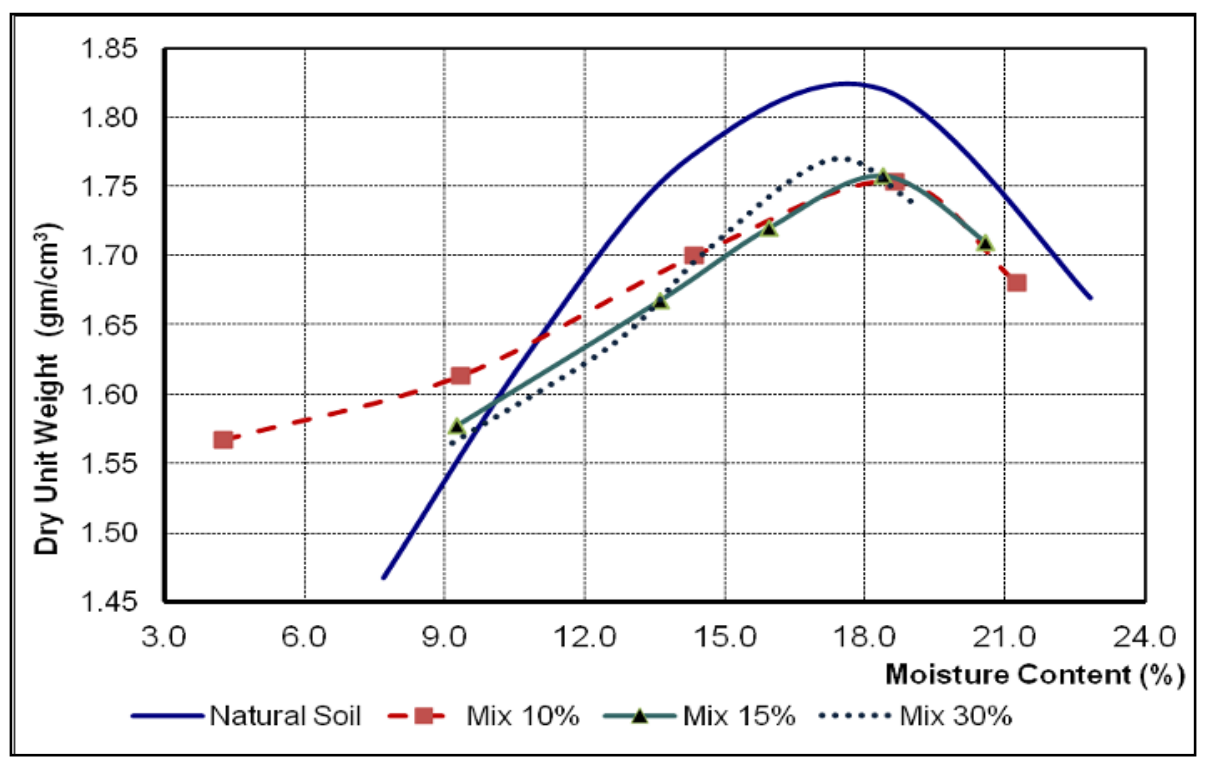

Fig. 2. Compaction test results

\subsubsection{California bearing ratio}

Figure 3 shows the CBR test for all mixtures. The values of the CBR tests were summarized in table 2. The results show that as cement dust ratio increases as the CBR value increases. The maximum CBR were obtained from mixture with $30 \%$ CKD ratio.

Journal of Engineering Sciences, Assiut University, Faculty of Engineering, Vol. 41, No. 4, July, 2013,E-mail address: jes@aun.edu.eg 
Mohie ElMashad, Ahmed Hashad, Improving the strength of sandy silt soils by mixing with cement kiln dust, PP. 1421 - 1431

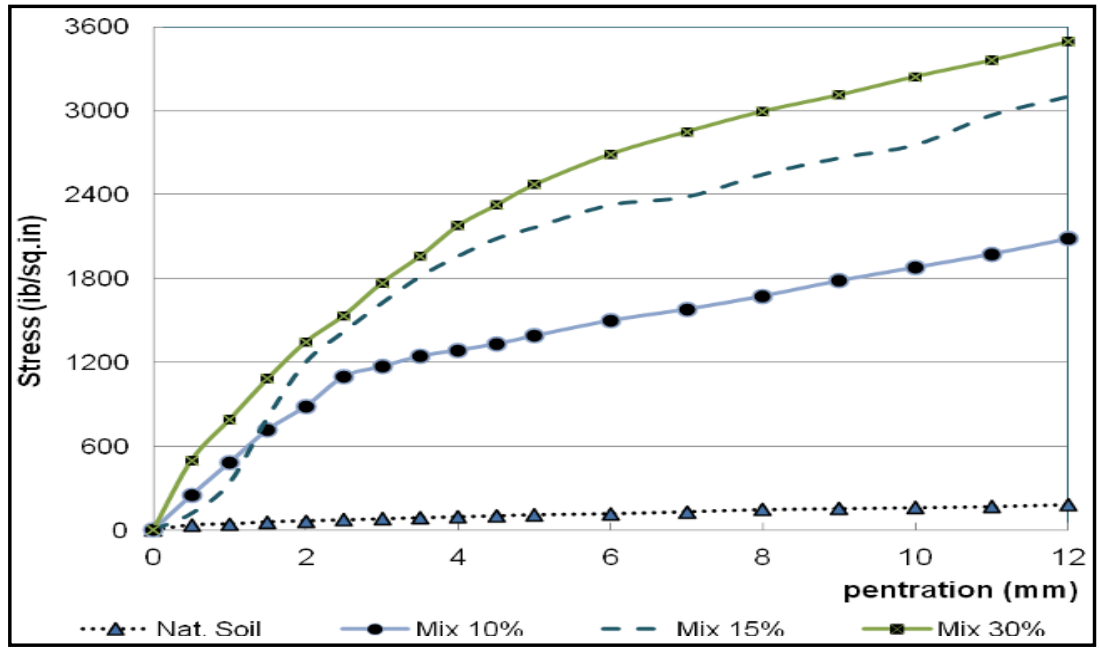

Fig. 3. California bearing ratio test

Table 2.

CBR values of the mixtures

\begin{tabular}{|l|c|c|c|c|}
\hline Soil mix & Nat. Soil & Mix 10\% & Mix 15\% & Mix 30\% \\
\hline CBR (\%) & 7.3 & 109 & 144 & 165 \\
\hline
\end{tabular}

\subsubsection{Unconfined compression test}

The most common indicator for soil improvement is the compressive strength. The unconfined compression stress of each mixture was determined at different ages. specimens of all the mixtures were cured by immersing in fresh water basin and were tested after 3,7 and 28 days. Figure (4) displays the value of unconfined compressive strength for mixtures against time.

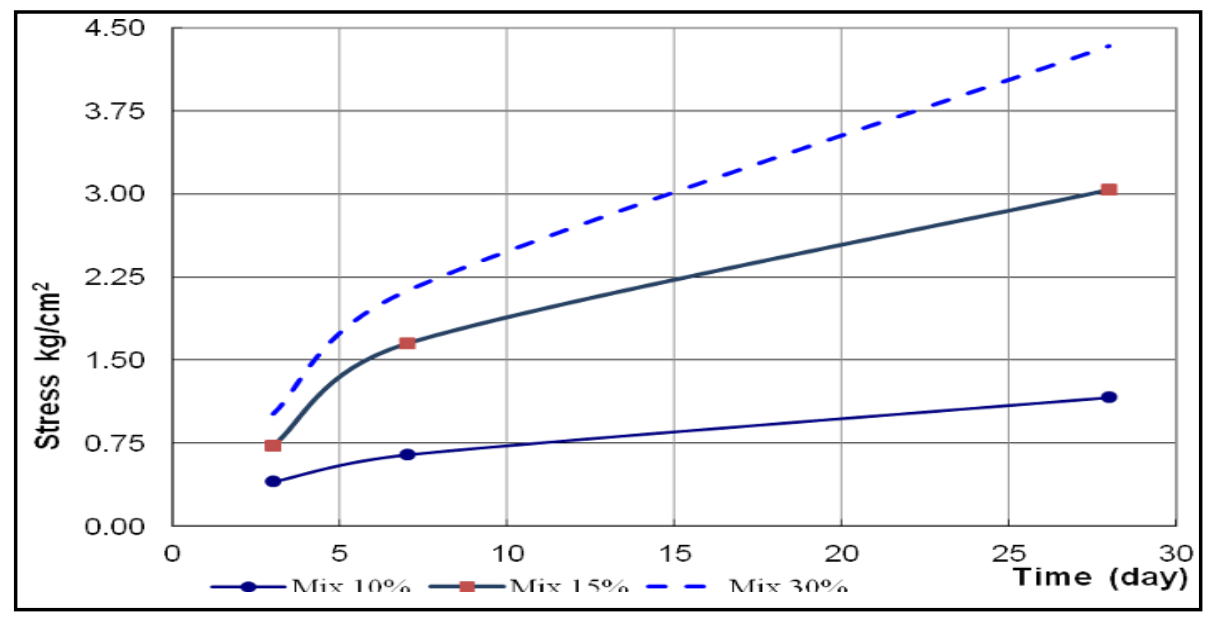

Fig. 4. Unconfined compression test results

Journal of Engineering Sciences, Assiut University, Faculty of Engineering, Vol. 41, No. 4, July, 2013, E-mail address: jes@aun.edu.eg 
Mohie ElMashad, Ahmed Hashad, Improving the strength of sandy silt soils by mixing with cement kiln dust, PP. 1421 - 1431

It can be noticed that as CKD ratio increases the mixture compressive strength increases. Also the compressive strength of the mixture increases with time.

\subsubsection{Unconsolidated undrained triaxial test (UU)}

The triaxial test is the most accurate test used to determine the shear strength parameters of the cohesive soils. The unconsolidated undrained test gives the shear strength of soil at different confining pressures. Results obtained from these tests can provide data for the understanding of basic soil behavior and soil properties that can be used in design. The samples were tested after seven days. The determined shear parameters of the natural soil and the three considered soil mixtures are summarized in table 3.

Table 3.

Shear Parameters Results

\begin{tabular}{|l|c|c|c|c|}
\hline Shear parameters & Nat. Soil & Mix 10\% & Mix 15\% & Mix 30\% \\
\hline$(\mathrm{C}) \mathrm{kg} / \mathrm{cm}^{2}$ & 0.12 & 0.28 & 0.66 & 1.04 \\
\hline$(\varphi)$ & 13 & 7 & 11 & 16 \\
\hline
\end{tabular}

Figure 5 shows the stress - strain relation for the natural soil and the three soil mixtures. The results show that as the CKD ratio increases the soil resistance increases.

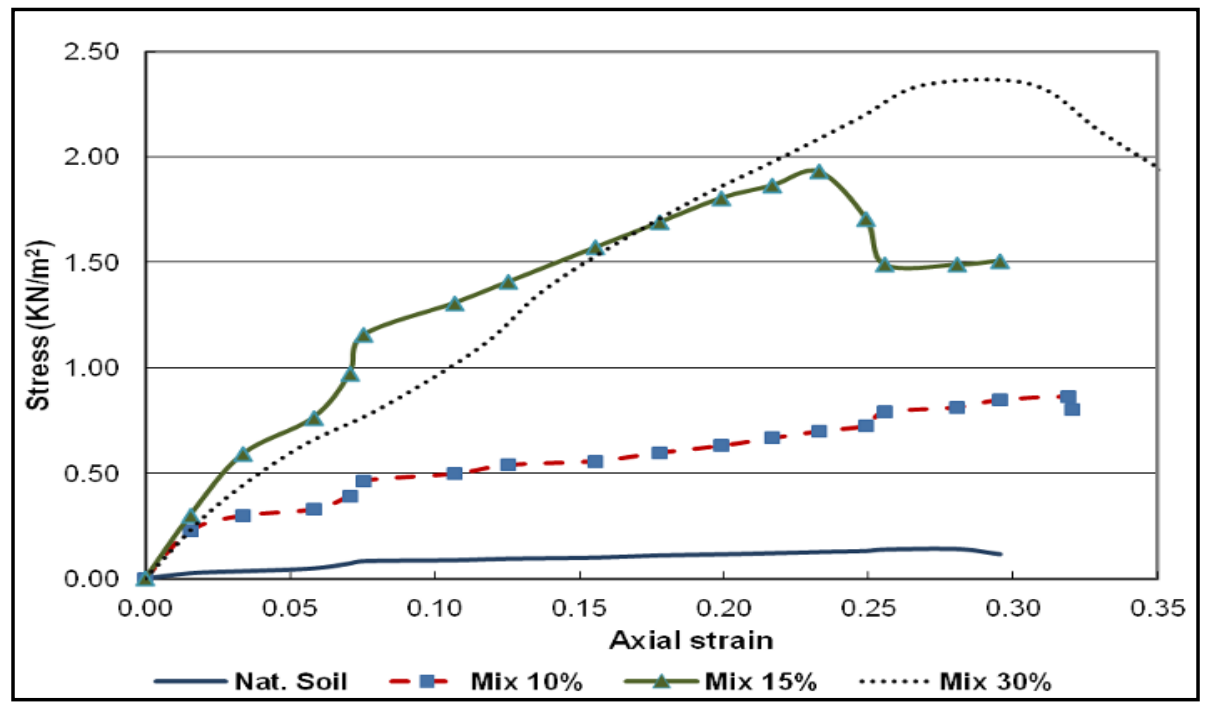

Fig. 5. Triaxial Test Results at $160 \mathrm{KN} / \mathrm{m}^{2}$ Confining Pressure

\subsubsection{Permeability test}

Permeability coefficients were determined form variable head permeability test for the natural soil and for each mixture. The values of permeability coefficient for natural soil and all soil mixtures with the different CKD ratios are shown in Figure (6). It is noticed that the mix with $15 \%$ CKD ratio has the minimum permeability coefficient, while the mix with $10 \%$ CKD ratio has the maximum permeability coefficient.

Journal of Engineering Sciences, Assiut University, Faculty of Engineering, Vol. 41, No. 4, July, 2013,E-mail address: jes@aun.edu.eg 
Mohie ElMashad, Ahmed Hashad, Improving the strength of sandy silt soils by mixing with cement kiln dust, PP. 1421 - 1431

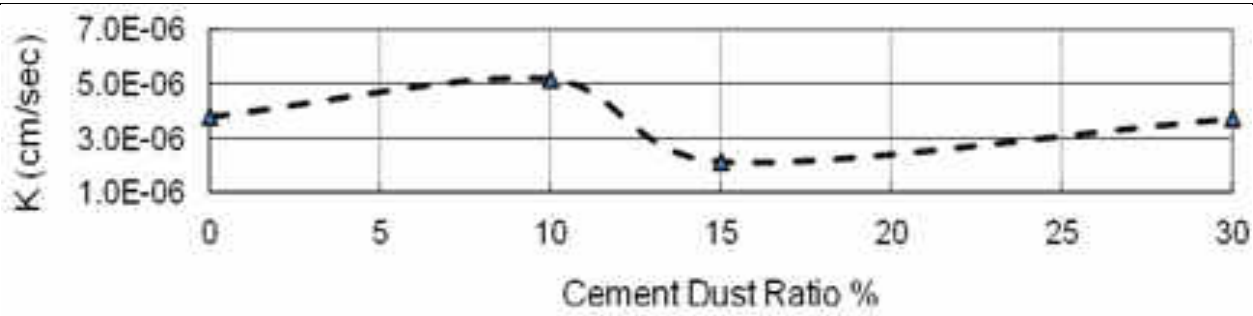

Fig. 6. Permeability Test Results

\section{Experimental results discussion}

Mixing sandy silt soil with CKD leads to increase the specific gravity of the mix because adding material with low density to another material with high density leads to get mix that has density value more than the lower one but with value near to the density that has the highest mixing ratio. Soil Compaction is sensitive to particle size distribution. Poor graded soils have limited improvement in its dry density when being compacted. Reviewing compaction tests results with the brain size distribution results lead to understanding the results of CKD mixtures compaction test. The worst effect in grain size distribution when increasing CKD ratio also leads to insignificant improvement in permeability of soil mix. It was found that as CKD ratio increases as soil mix cohesive stress increases. This was cleared by results of unconfined compressive test, CBR test, and triaxial test.

\section{Numerical analysis}

A numerical model for an embankment of one of Egyptian canals was built to study the ability of the proposed method to improve the canal embankment slope stability. The numerical model is used to compare the safety factor before and after using the proposed soil improvement method, moreover, the safety factor was calculated again when using traditional soil reinforcement techniques. A soil stratum consists of one layer of sandy silt with traces of clay with $15.00 \mathrm{~m}$ depth and $45.00 \mathrm{~m}$ width this layer was under a fill layer with depth $1.00 \mathrm{~m}$. A finite element numerical analysis using nonlinear elasto-plastic analysis was performed using Plaxis 8.2 professional version [5]. Figure (7) shows the finite element mesh of the soil strata. A plane strain element with 15 nodes and Mohr-Coulomb soil model were used in the analysis.

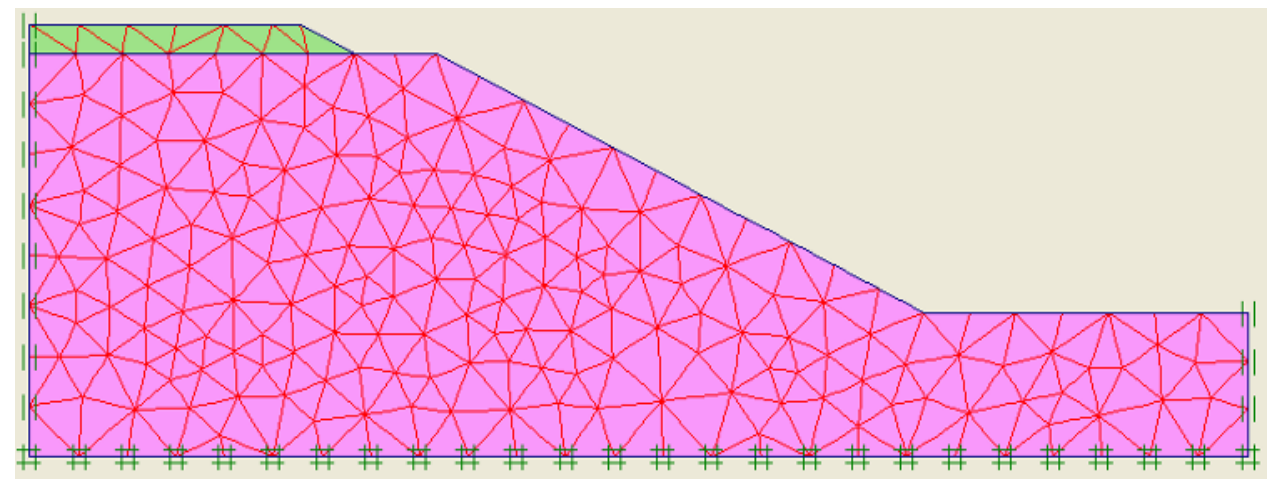

Fig. 7. Finite Element Model for Unimproved Soil

Journal of Engineering Sciences, Assiut University, Faculty of Engineering, Vol. 41, No. 4, July, 2013,E-mail address: jes@aun.edu.eg 
1428

Mohie ElMashad, Ahmed Hashad, Improving the strength of sandy silt soils by mixing with cement kiln dust, PP. 1421 - 1431

The improved soil was simulated with plane strain elements with 15 nodes. The properties of soil-cement dust (mixed soil) elements used in the model are shown in table (4) for various mixtures. These properties were determined from experimental work.

\section{Table 4.}

Properties of Soil mix elements

\begin{tabular}{|l|c|c|c|c|}
\hline Soil Properties & Nat. Soil & Mix 10\% & Mix 15\% & Mix 30\% \\
\hline$(\mathrm{C}) \mathrm{KN} / \mathrm{m}^{2}$ & 12 & 28 & 66 & 104 \\
\hline$(\varphi)$ & 13 & 7 & 11 & 16 \\
\hline Young's modulus $\mathrm{K}_{\mathrm{N}} / \mathrm{m}^{2}$ & 13000 & 13050 & 13100 & 13150 \\
\hline Density $\mathrm{K}_{\mathrm{N}} / \mathrm{m}^{3}$ & 18.1 & 17.5 & 17.5 & 17.8 \\
\hline Posson's ratio & 0.35 & 0.34 & 0.33 & 0.31 \\
\hline Permeability $(\mathrm{K})(\mathrm{cm} / \mathrm{sec})$ & $3.7 \times 10^{-6}$ & $5.1 \times 10^{-6}$ & $2.1 \times 10^{-6}$ & $3.7 \times 10^{-6}$ \\
\hline
\end{tabular}

The improved soil mass was defined in the finite element mesh as shown in figure (8). The boundary of the improved soil mass that was mixed with CKD is considered outside of the critical slip circle of the original natural soil by $1.00 \mathrm{~m}$.

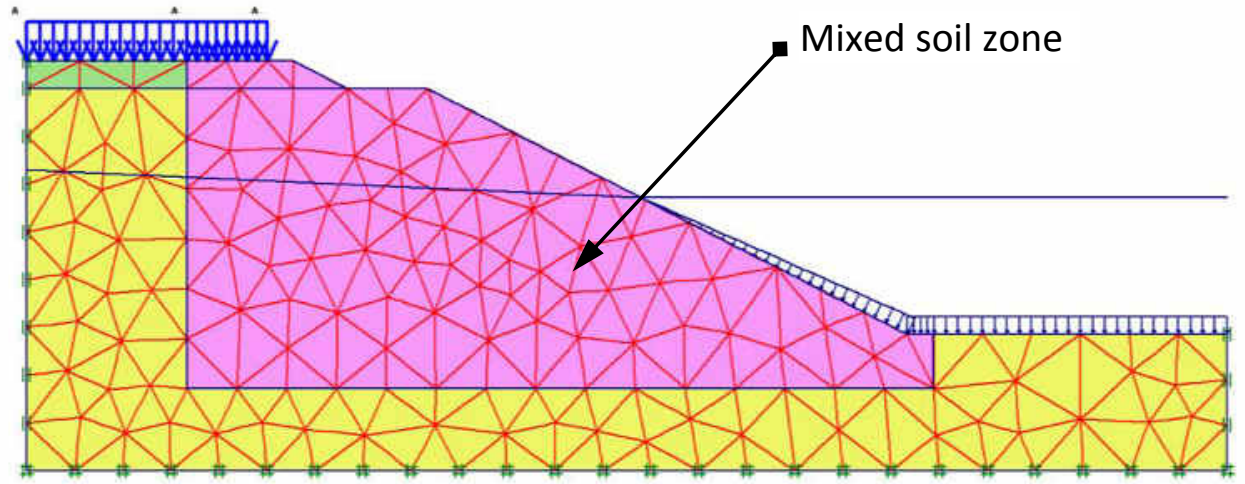

Fig. 8. Finite Element Model for Improved Soil

The factors of safety increasing ratio for various mixtures are shown in table 5. The increasing safety ratio (I.S.R) was calculated according to equation No. 1 I.S.R = (improved factor of safety / unimproved factor of safety) ...........eq. 1

Table 5.

Increasing Safety Ratio (I.S.R) - Soil Mix Technique

\begin{tabular}{|l|c|c|c|}
\hline Soil Type & Mix 10\% & Mix 15\% & Mix 30\% \\
\hline I.S.R & 1.50 & 2.30 & 2.44 \\
\hline
\end{tabular}

Where I.S.R is the increasing safety ratio

Journal of Engineering Sciences, Assiut University, Faculty of Engineering, Vol. 41, No. 4, July, 2013, E-mail address: jes@aun.edu.eg 
Mohie ElMashad, Ahmed Hashad, Improving the strength of sandy silt soils by mixing with cement kiln dust, PP. 1421 - 1431

The proposed method was compared with the traditional soil improved method using soil reinforcement technique. The unimproved soil model was updated by adding layers of geogrid. The factor of safety was calculated for cases of using 1,2,3 and 9 geogrid layers. Figure (9) shows the finite element model for case of adding 9 layers of geogrid. The increasing safety ratio for various mixtures is shown in table 6 .

Table 6.

Increasing Safety Ratio (I.S.R) - Soil Reinf. Technique

\begin{tabular}{|l|c|c|c|c|}
\hline Soil Type & 1 layer & 2 layer & 3 layer & 9 layer \\
\hline I.S.R & 1.02 & 1.03 & 1.04 & 1.06 \\
\hline
\end{tabular}

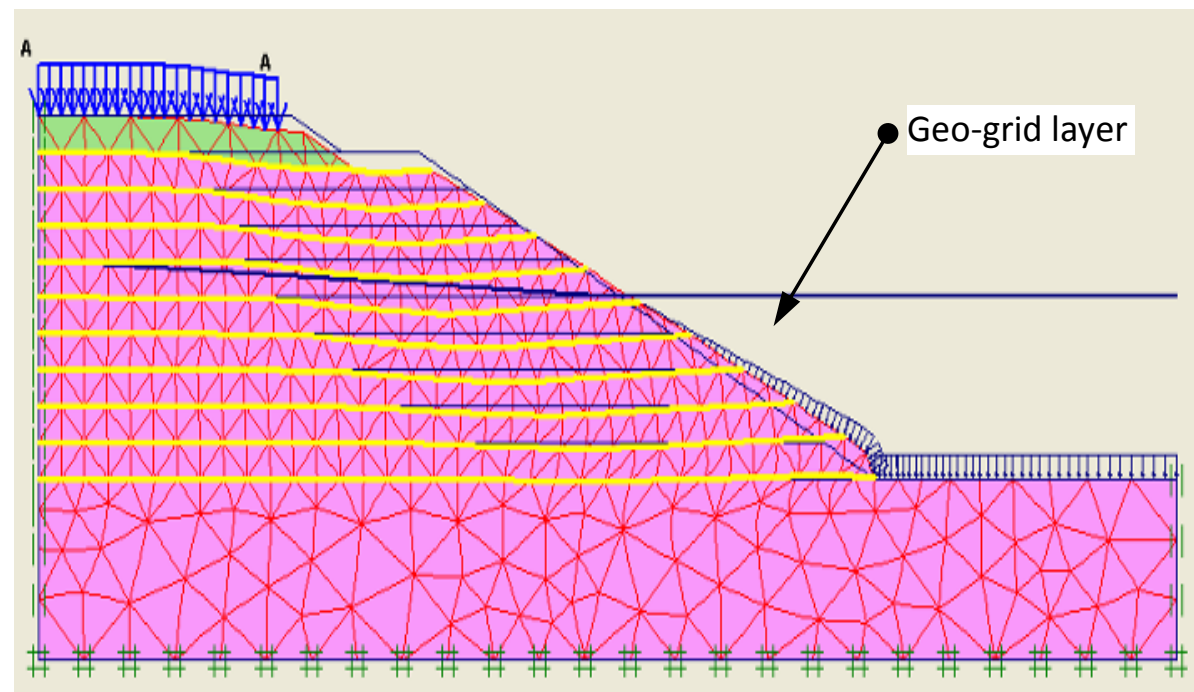

Fig. 9. The $9^{\text {th }}$ geo-grid layer Finite Element Model

\subsection{Numerical analysis results}

The results obtained from the finite element model of the embankment slope stability problem shows that the safety factor was doubled several times which is mean that, the proposed method is able to achieve high rates of safety. The results also showed that the soil reinforcement technique for sandy silt soils, however the number of geo-grid layers used, has a very limited impact in increasing safety factor.

\section{Conclusions}

The proposed method showed its ability to improve significantly the shear resistance of the sandy silt soils. The effectiveness of cement kiln dust depends on the soil treated and the amount of additive used. In general, Results that have been reached in this research, which relied on an appropriate level of laboratory tests to reach the appropriate degree of

Journal of Engineering Sciences, Assiut University, Faculty of Engineering, Vol. 41, No. 4, July, 2013, E-mail address: jes@aun.edu.eg 
1430

Mohie ElMashad, Ahmed Hashad, Improving the strength of sandy silt soils by mixing with cement kiln dust, PP. 1421 - 1431

accuracy gives very encouraging signs to expand the use of CKD in improving soil properties. It is recommended based on the results of this research that cement dust to be considered a viable option for the soil improving. This study leads to the following conclusions:-

1. The use of soil mix with cement dust to improve sandy silt soils has no significant effect on the dry density ratio or on the permeability coefficient.

2. The results of tri-axial, unconfined compressive strength and bearing stress tests showed an impressive improvement.

3. Numerical analysis results showed encouraging results, either from economic point of view or safety rates point of view.

4. Further studies must be carried out to study mix durability.

\section{Rreferences}

[1] Wayne S. Adaska, Donald H. Taubert.," Beneficial Uses of Cement Kiln Dust ", $50^{\text {th }}$ Cement Industry Technical Conference, Paper No. 1627, Miami,USA, May, 2008.

[2] Robert L. Parsons, Elizabeth Kneebone, and Justin P., "Use of Cement Klin Dust for Subgrade Stabilization", Bureau of Materials and Research, Kansas Department of Transportation, Final Report, No. KS-04-3, October, 2004.

[3] Mohie Eldin Elmashad "Soil Improvement using Cement Dust Mixture" Journal of World Academy of Science, Engineering and Technology, Vol. 58, pp. 413-416,2011.

[4] P.V.Koteswara, K.Satish and T.Blessingstone "Performance of Recron - 3S Fiber With Cement Kiln dust in Expansive Soils" International Journal of Engineering Science and Technology (IJEST) Vol. 4 No.04, pp. 1361-1366, April 2012.

[5] Plaxis Professional Ver. 8.2, Delft University of Technology and Plaxis b. v., The Netherlands, 2002.

[6] Barron, R. F., Kramer, C., Herlache, W. A., Wright, J., Fung, H., and Chu Liu., "Cement Deep Soil Mixing Remediation of Sunset North Basin Dam". http://www.cement.org/water/dams_sc_cdsm.asp. (2006).

[7] Allison Mackie, Heather Farmer, Margaret Walsh., "Mine Water Treatment with Cement Kiln Dust (CKD)". IMWA, pp. 139-142,Sydney, 2010.

Journal of Engineering Sciences, Assiut University, Faculty of Engineering, Vol. 41, No. 4, July, 2013, E-mail address: jes@aun.edu.eg 
Mohie ElMashad, Ahmed Hashad, Improving the strength of sandy silt soils by mixing with cement kiln dust, PP. 1421 - 1431

تحسين مقاومة التربة الطمي رملية عن طريق خلطها بغبار الاسمنت

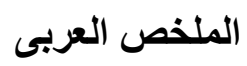

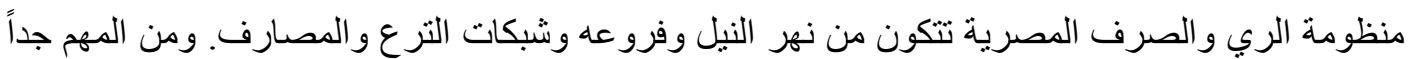

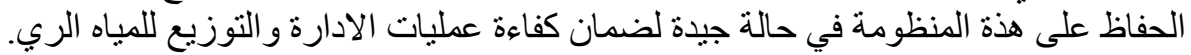

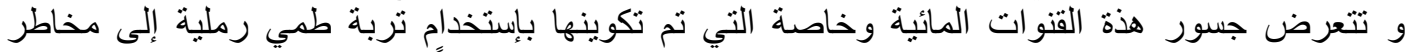

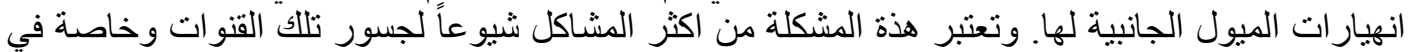
منطقة الدلتا. تعتبر طرق تحسين التربة من اكثر الاساليب الهندسية إقتصاداً لمعالجة مشكلات التربة ويتناول هذا البحث

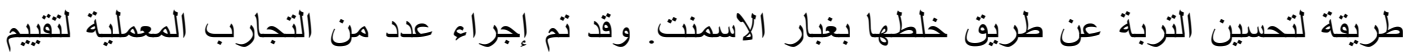

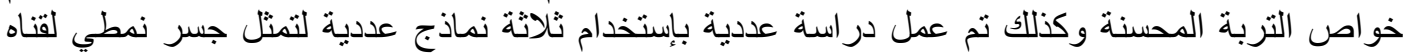

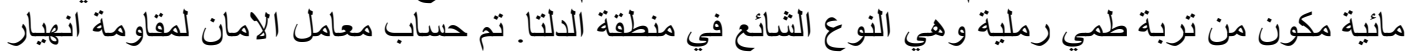

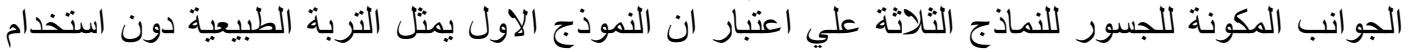

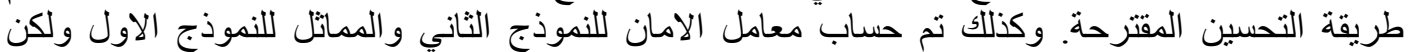

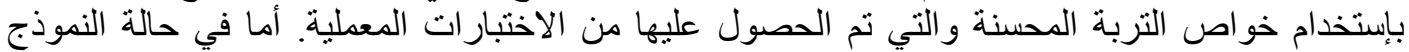

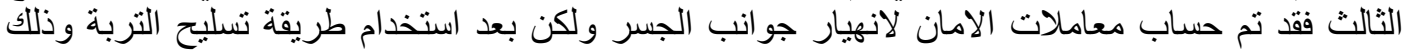

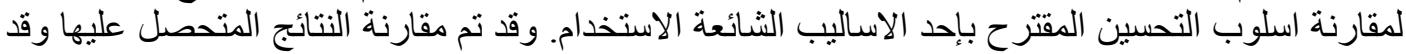
اظهرت النتائج فاعلية الطريقة المقترحة.

Journal of Engineering Sciences, Assiut University, Faculty of Engineering, Vol. 41, No. 4, July, 2013,E-mail address: jes@aun.edu.eg 